\title{
Unintentional introduction of aquatic molluscs from Poland to Prague (Czech Republic)
}

\author{
LUBOŠ BERAN \\ Kokořinsko Protected Landscape Area Administration, Česká 149, CZ-27601 Mělník, Czech Republic, lubos.beran@schkocr.cz
}

BERAN, L., 2006: Unintentional introduction of aquatic molluses from Poland to Prague (Czech Republic). - Malacologica Bohemoslovaca 5: 6-9. Online serial at < http://mollusca.sav.sk> 18-February-2006.

\begin{abstract}
The aquatic mollusc populations of a restored water reservoir N1 - Stodůlky (Prague Capital City, Czech Republic, Elbe River Basin) were studied during 2005. Two visits, one and two months after inundation of the reservoir revealed rapid colonisation by 14 species of aquatic molluses and the introduction of eight species (Valvata macrostoma, Stagnicola palustris s. str., S. corvus, Planorbis planorbis, Bathyomphalus contortus, Anisus spirorbis, A. septemgyratus, Segmentina nitida) from a site in north-western part of Poland (Tuchola region, Wisla River Basin about 450 $\mathrm{km}$ distant). These molluscs were transported on coir rollers and matting which were used for stabilisation of the reservoir banks during restoration.
\end{abstract}

\section{Introduction}

Introductions and expansions of alien or non-native aquatic molluscs in the territory of Europe have been studied in numerous cases and the Czech Republic is not an exception in this respect (e.g. BERAN 1994, 1997a, 1997b, 2000, 2002, 2003, BERAN \& HORSÁK 2002b). However, the situation is different in the case of introductions and transfers of autochthonous species among different regions, countries, river basins or marine drainage areas. The main reason for this difference is the limited possibilities for recording the introduction of autochthonous species and the need to be familiar with their source area. The case described below is a good example of the introduction of several species of aquatic molluscs from the north-eastern part of Poland to Prague (Czech Republic) and of their rapid colonisation of a restored water reservoir.

\section{Material and Methods}

During 2005 the author studied aquatic molluscs in selected water reservoirs and ponds in the territory of Prague. A water reservoir N1 - Stodůlky (geographical coordinates $-50^{\circ} 02^{\prime} 51^{\prime \prime} \mathrm{N}, 14^{\circ} 19^{\prime} 42^{\prime \prime} \mathrm{E}$, code for faunistic grid mapping 5951 (cf. PRUNER \& MíkA 1996), altitude $317.6 \mathrm{~m}$ a.s.l.) was one of the sites studied and was visited on June $19^{\text {th }}$ and on July $10^{\text {th }}$. This water reservoir has an area of 1.7 hectares and a maximum depth of approximately 3 metres. It was built about 30 year ago on the Prokopský potok brook. In autumn 2004 it was drained and during the winter of 2004/2005 was rebuilt. Reconstruction comprised removal of sediment from the deeper sections and stabilisation of the reservoir banks with coir rollers of $30 \mathrm{~cm}$ diameter (scrolled matting) and flat matting. The water reservoir was re-filled with water less than one month before the author's first visit. Information given in this paper concerning the reconstruction techniques and the coir rollers and matting (cultivation of vegetation, transport) were obtained from a signboard situated on the bank of the reservoir, from personal communication with $\mathrm{J}$. Karnecki (Authority of the Prague Capital City), and from the electronic presentations of Hydrolech Ltd.

The most common sampling method for aquatic molluscs is the washing of vegetation or sediments and collection with a metal sieve (a kitchen strainer, diameter $20 \mathrm{~cm}$, mesh size $0.5-1 \mathrm{~mm}$ ). This method (washing vegetation on selected sites along the bank of the water reservoir) could be used during the second visit when the coir rollers 
covered with vegetation were below the water level $(5-25 \mathrm{~cm})$. However, during the first visit, molluscs were found only on plastic bags and stones on the bottom of the reservoir close to the pond banks. At this time the rollers were above the water level and only one month after filling up stones and plastic bags represented the only environment for molluscs (sediment or vegetation having not yet occurred at the site). Nearly all plastic bags present and a selection of stones were observed during the first visit. The duration of searching was the same (approximately 1 hour) during both visits. Molluscs were mainly determined by their conchs. Only specimens of the genus Stagnicola were dissected after killing with hot water and identified on the base of their copulatory organs. The classification used is that of BERAN (2002). Conchs of Valvata macrostoma, Stagnicola palustris s. str., Anisus spirorbis, A. septemgyratus are deposited in the author's collection.

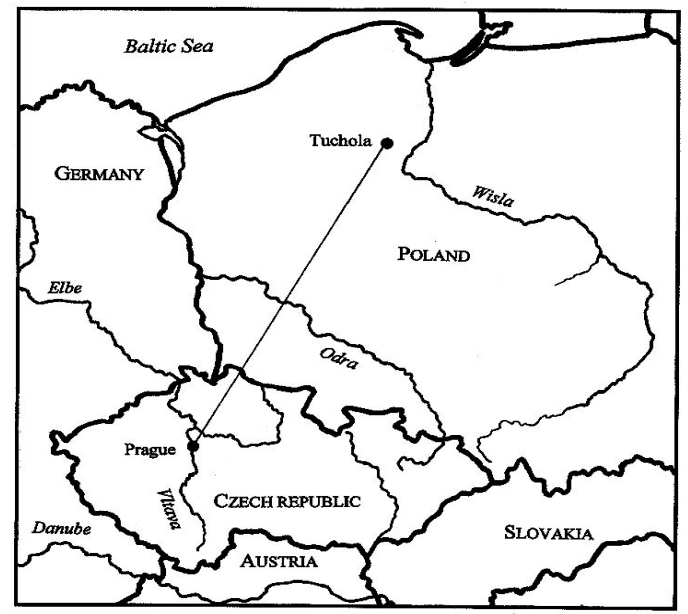

Fig. 1. Map of Europe with target and source areas of introduction.

\section{Results and discussion}

During the two visits the presence occurrence of 14 species of aquatic molluscs was documented (Table 1). Their occurrence only one or two months after filling up of the reservoir is very surprising. Such a rapid colonisation by aquatic molluses and the dramatic expansion during the period between the two visits is unusual. However, in the case of Galba truncatula, Radix auricularia, Lymnaea stagnalis, Physella acuta, Gyraulus albus and $G$. crista it is explicable. Molluscs of these species could colonise this site from Prokopský potok brook which flows through the water reservoir or may have been introduced by birds, e. g., the wild duck (Anas platyrhynchos). All six species are relatively common in adjacent water bodies (brooks, ponds, water reservoirs) in this region and they belong to species which inhabit new or restored water bodies very soon after inundation. Also it is not ruled out that these snails could have lived in the reservoir earlier (samples were not collected before the reservoir was emptied and cleaned) and survived in moist areas and in the sediment during the reconstruction.

More surprising was the occurrence of the other eight species (Valvata macrostoma, Stagnicola palustris s. str., S. corvus, Planorbis planorbis, Bathyomphalus contortus, Anisus spirorbis, A. septemgyratus, Segmentina nitida). The last three species were dominant during the second visit. All these molluscs usually inhabit overgrown water bodies in later seral stages, temporary pools or wetlands (cf. BERAN 2002). According to JUŘIČKOVÁ (1995) and BERAN (2002) Stagnicola corvus, Planorbis planorbis and Bathyomphalus contortus very rarely occur in Prague, while the other five species have never been found in this region. $\mathrm{Val}$ vata macrostoma is a very rare mollusc for the Czech Republic. It usually settles in temporary pools and wetlands in lowlands and recently has been found at 2 sites in Elbe River Lowland near Mělník (BERAN 2002). Anisus septemgyratus is known in the Czech Republic only in Southern Moravia (Dyje River Basin) where it is found in pools and wetlands in floodplain forests (BERAN \& HORSÁK 2002a). On the basis of this evidence, the occurrence of these species is considered surprising and natural introduction (e.g., by birds) of all eight species is thought to be very improbable. The only reasonable explanation for their occurrence is their introduction via the coir rollers and matting used for the restoration. The coir rollers and matting which were used for the stabilisation of the reservoir banks had been placed in water tanks for two years before their use and wetland plants (e. g., Carex spp., Iris pseudacorus, Acorus calamus) had been cultivated on them. This cultivation occurred in the north-west of Poland near the town of Tuchola (Wisla River Basin, about $450 \mathrm{~km}$ distant from Prague) in the facility of Hydrolech Ltd. The rollers and matting with wetland vegetation were then transported from Poland to Prague to the Stodůlky water reservoir. Strong evidence for the presence of molluscs in the water tanks in Poland was provided by the many empty shells of Stagnicola spp., Planorbis planorbis, Anisus spirorbis, A. septemgyratus, Bathyomphalus contortus, Segmentina nitida and Planorbarius corneus which were found on rollers and matting during the first visit (June). Thus, there is strong evidence that some individuals of all species except for Planorbarius corneus had survived the transport and sub- 
sequently colonised the water reservoir in Stodůlky despite the fact that this habitat is generally not suitable for species occurring in shallow and overgrown stagnant aquatic habitats.

These observations show how human activities can directly cause dispersion of living organisms including aquatic molluscs. The continuing survival and maintenance of the eight introduced species in this new habitat will depend on a range of environmental factors including habitat stability, vegetation, fish stock, and physico-chemical water characteristics. However, in the case of several species it is possible that they will persist, and therefore it will be interesting to observe further development of their populations.

Acknowledgements: I would like to express my gratitude to J Karnecki for the technical information concerning the restoration including the presentation of Hydrolech Ltd. and to P. Roth for his critical remarks on the manuscript and his help with the English.

\section{References}

BERAN L., 1994: Severoamerický okružák Menetus dilatatus (Gould) v České republice. [American freshwater snail Menetus dilatatus (Gould) in the Czech Republic (Mollusca: Gastropoda)]. - Práce muzea v Kolíně, řada prŕrodovědná, 1: 31-32.

BERAN L., 1997a: First record of Sinanodonta woodiana (Mollusca: Bivalvia) in the Czech Republic. - Acta Soc. Zool. Bohem., 61: 1-2.
BERAN L., 1997b: Menetus dilatatus (Gould, 1841) (Mollusca, Gastropoda) in the Czech Republic. Časopis Nár. muz., Řada př́rodovědná, Vol. 166 (1-4): 59-62. BERAN L., 2000: First record of Corbicula fluminea (Mollusca: Bivalvia) in the Czech Republic. - Acta Soc. Zool. Bohem., 64: 1-2.

BERAN L., 2002: Vodní měkkýši České republiky - rozšíření a jeho změny, stanoviště, šíření, ohrožení a ochrana, červený seznam [Aquatic molluscs of the Czech Republic - distribution and its changes, habitats, dispersal, threat and protection, Red List]. - Sborník př́rodovědného klubu v Uh. Hradišti, Supplementum 10, 258 pp.

BERAN L., 2003: Nález severoamerického druhu Menetus dilatatus (Mollusca: Gastropoda) v jižních Čechách (Česká republika). [Record of Menetus dilatatus (Mollusca: Gastropoda) in the Southern Bohemia (Czech Republic)]. - Malacologica Bohemoslovaca (Československá slimač), 2: 1-2.

BerAN L. \& HorsáK M., 2002a: Anisus septemgyratus (Mollusca: Gastropoda) in the Czech Republic, with notes to its anatomy. - Acta Soc. Zool. Bohem., 66: 231234.

BERAN L. \& HorSÁK M., 2002b: Gyraulus parvus (Mollusca: Gastropoda) in the Czech Republic. - Acta Soc. Zool. Bohem., 66: 81-84.

JUŘIČKOVÁ L., 1995: Měkkýší fauna Velké Prahy a její vývoj pod vlivem urbanizace. [Molluscan fauna in the territory of Prague agglomeration and its development in urban influence]. - Natura Pragensis, Praha, 12, 212 pp. (in Czech).

PRUNer L. \& Míka P., 1996. Seznam obcí a jejich částí v České republice s čísly mapových polí pro sítové mapování fauny [List of settlements in the Czech Republic with associated map field codes for faunistic grid mapping system]. - Klapalekiana, 32, Suppl.: 1-175.

Table 1. List of species found in water reservoir Stodůlky

\begin{tabular}{|c|c|c|}
\hline \multirow[t]{2}{*}{ SPECIES (Family) } & \multicolumn{2}{|c|}{ NUMBER OF INDIVIDUALS } \\
\hline & 19th June 2005 & 10th July 2005 \\
\hline \multicolumn{3}{|l|}{ Valvatidae } \\
\hline Valvata macrostoma Mörch, 1864 & & 1 \\
\hline \multicolumn{3}{|l|}{ Lymnaeidae } \\
\hline Galba truncatula (O. F. Müller, 1774) & 3 & \\
\hline Stagnicola palustris (O. F. Müller, 1774) s. str. & & 5 \\
\hline Stagnicola corvus (Gmelin, 1791) & 2 & 1 \\
\hline Radix auricularia (Linnaeus, 1758) & 25 & ca 40 \\
\hline Lymnaea stagnalis (Linnaeus, 1758) & 4 & $50-100$ \\
\hline \multicolumn{3}{|l|}{ Physidae } \\
\hline Physella acuta (Draparnaud, 1805) & 30 & $50-100$ \\
\hline \multicolumn{3}{|l|}{ Planorbidae } \\
\hline Planorbis planorbis (Linnaeus, 1758) & 13 & ca 35 \\
\hline Anisus spirorbis (Linnaeus, 1758) & 4 & $50-100$ \\
\hline Anisus septemgyratus (Rossmaessler, 1835) & & $50-100$ \\
\hline Bathyomphalus contortus (Linnaeus, 1758) & & 4 \\
\hline Gyraulus albus (O. F. Müller, 1774) & 3 & $50-100$ \\
\hline Gyraulus crista (Linnaeus, 1758) & 7 & 5 \\
\hline Segmentina nitida (O. F. Müller, 1774) & 4 & 30 \\
\hline
\end{tabular}




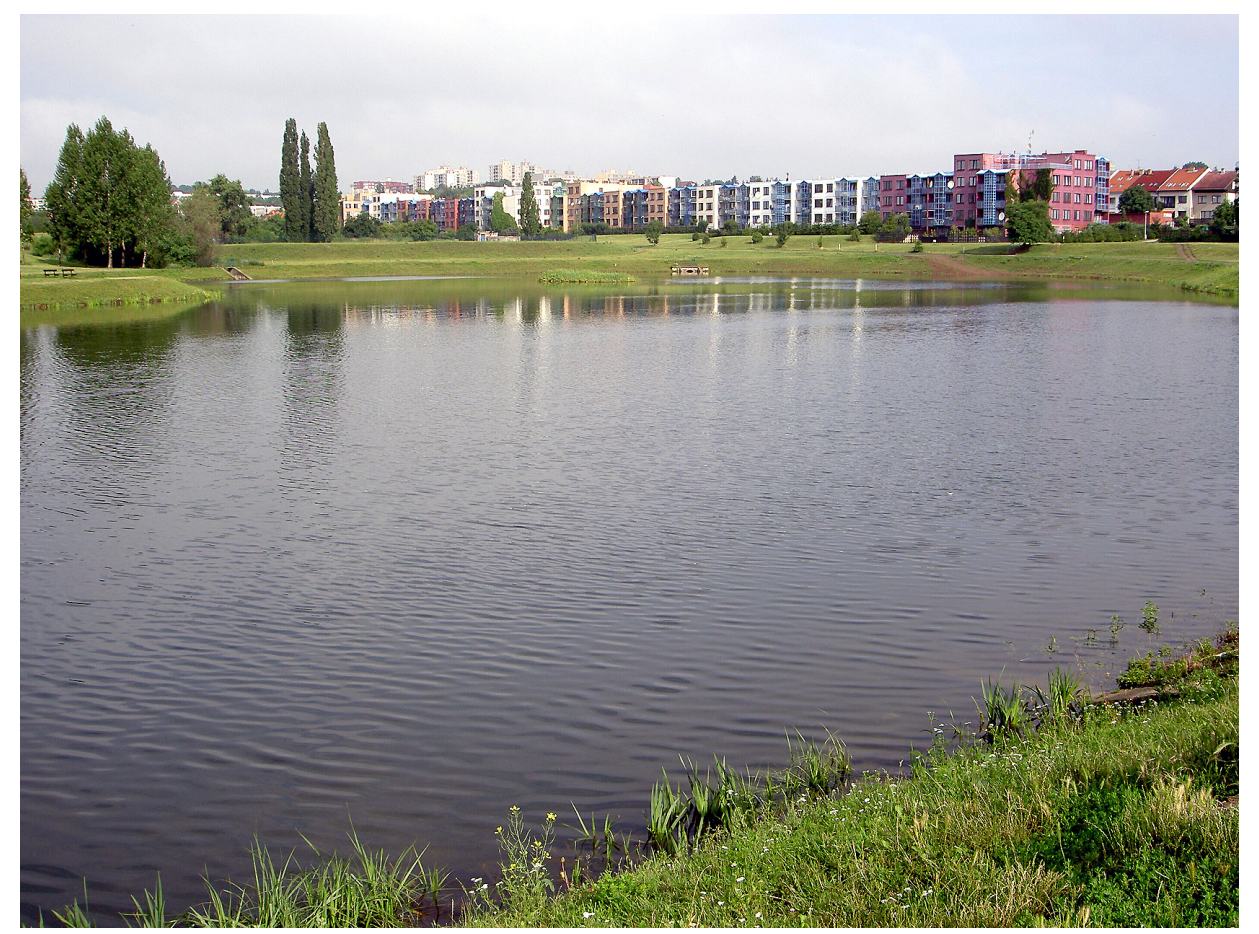

Fig. 2. The restored water reservoir N1 - Stodůlky, Prague, Czech Republic. Photo L. Beran.

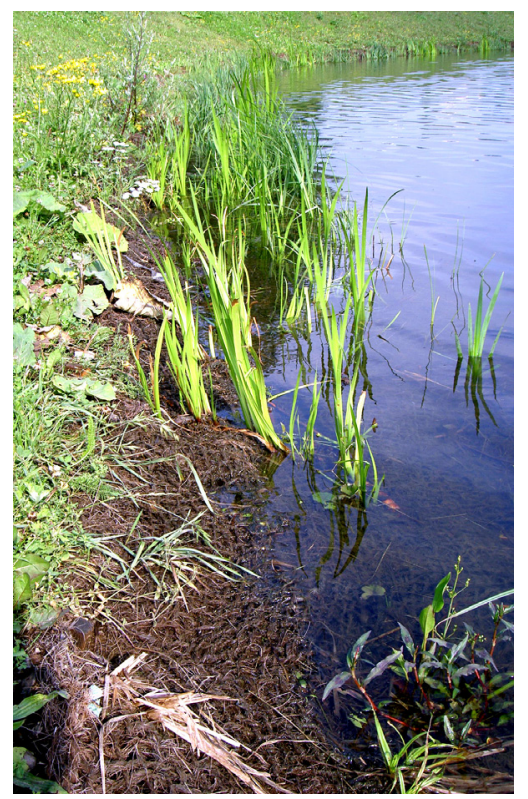

Fig. 3. Bank of the restored water reservoir stabilised with coir rollers with cultivated vegetation. Photo L. BERAN. 